\title{
EFIKASI DIRI PERAWAT TERHADAP PENERAPAN ASUHAN PERKEMBANGAN (DEVELOPMENTAL CARE)
}

\author{
Armina $^{1}$, Happy Hayati ${ }^{2}$, Nani Nurhaeni ${ }^{3}$ \\ ${ }^{1}$ Program Studi Profesi Ners STIKes Baiturrahim Jambi \\ ${ }^{2,3}$ Departemen Keperawatan Anak,Fakultas Ilmu Keperawatan Universitas Indonesia \\ Email : arminanurwa86@gmail.com
}

\begin{abstract}
The neonatal nursing room in several hospitals in Indonesia has been widely disseminated about the application of developmental care but there are still many nurses who have not applied due to lack of nurse confidence (self efficacy is lacking). This study aims to identify the relationship between self efficacy factors and the application of developmental care by nurses in the neonate care unit. This study used cross sectional study design with 82 samples of nurses in neonate level I, II, III at two hospitals in RSAB Harapan Kita and RSPAD GatotSubroto. The instrument used is self-efficacy questionnaire and Indonesian translation instrument Universe develomental care (UDC). The data of this study were analyzed using bivariate analysis with independent $T$ test. The result of bivariate analysis showed that there was a relationship between the application of developmental care with self efficacy of neonate nurse with $p=0,017$. The researcher suggests the institution of nursing services to be able to facilitate the provision of funds and training for increase skill and confidence self nurses in the neonate room.
\end{abstract}

Keywords : developmental care, nurse, self efficacy

\begin{abstract}
ABSTRAK
Bayi prematur membutuhkan asuhan perkembangan (Developmental Care) yang adekuat.Ruang perawatan neonatus di beberapa rumah sakit di Indonesia sudah banyak disosialisasikan mengenai penerapan Developmental care namun masih banyak perawat yang belum menerapkan dikarenakan kurangnya keyakinan perawat (efikasi diri kurang). Penelitian ini bertujuan untuk mengidentifikasi hubungan antara faktor efikasi diri dengan penerapan asuhan perkembangan oleh perawat di ruang rawat neonatus. Penelitian ini menggunakan desain cross sectional study dengan jumlah sampel sebanyak 82 perawat di ruang perawatan neonatus level I, II, III di dua rumah sakit yaitu di RSAB Harapan Kita dan RSPAD Gatot Subroto. Instrumen yang digunakan adalah kuesioner efikasi diri dan instrumen terjemahan Indonesia Universedevelomental care(UDC). Data penelitian ini dianalisis menggunakan analisis bivariat dengan uji $\mathrm{T}$ independent. Hasil analisis bivariat menunjukkan bahwa ada hubungan antara penerapan asuhan perkembangan dengan efikasi diri perawat neonatus dengan nilai $\mathrm{p}=0,017$. Peneliti menyarankan institusi pelayanan keperawatan untuk dapat memfasilitasi pelatihan untuk meningkatkan kemampuan dan keyakinan diri perawat di ruang neonatus.
\end{abstract}

Kata kunci : asuhan perkembangan, efikasi diri, perawat. 


\section{PENDAHULUAN}

Periode bayi baru lahir merupakan masa yang kritis karena harus melakukan proses adaptasi segera dengan lingkungan luar kandungan terutama yang dialami bayi prematur. Indonesia menjadi salah satu negara dengan kejadian bayi lahir prematur tertinggi dunia dengan jumlah bayi prematur lebih dari $60 \%$ yaitu 675.700 pada tahun 2010 (WHO, 2012). Upaya perawatan ekstra untuk bayi prematur dan meminimalkan angka kematian yang direkomendasikan WHO (2012) diantaranya kangaroo mother care, inkubator, topi bayi, selimut dan menunda memandikan bayi untuk mencegah kehilangan panas (hipotermia), menurunkan risiko infeksi, dan menghindarkan bayi dari respiratory distress syndroma (RDS).

Bayi prematur yang dapat bertahan hidup masih dapat mengalami keterlambatan perkembangan dan gangguan perilaku (WHO, 2012). Upaya lain juga diarahkan pada perkembangan perilaku bayi prematur yang berkaitan dengan perkembangan otak bayi (Kenner \& McGrath, 2004) melalui penerapan asuhan perkembangan (developmental care) (Mosqueda et al., 2013).

Asuhan perkembangan memiliki dampak positif bagi bayi baru lahir terutama bayi prematur. Hasil penelitian Herliana (2012) menemukan bahwa bayi prematur usia 28 - < 37 minggu yang dilakukan asuhan perkembangan sebelum prosedur invasif mengalami penurunan respon nyeri dibandingkan kelompok kontrol.
Dampak positif lain dari hasil penelitian KiechlKohlendorfer et al. (2015) yaitu bayi prematur usia kurang dari 32 masa gestasi yang diberikan asuhan perkembangan mengalami penurunan keterlambatan perkembangan psikomotor pada usia dua tahun dibandingkan kontrol grup. Hal ini menunjukkan bahwa asuhan perkembangan pada bayi prematur memberi dampak positif baik jangka pendek maupun jangka panjang.

Hasil penelitian yang dilakukan Godarzi et al. (2015) menemukan bahwa perawat melakukan perawatan rutin setiap hari pada bayi $(79,46 \%)$; sedangkan melakukan asuhan perkembangan sebesar 66,53\%, diantaranya proteksi tidur $(65,43 \%)$, memperbaiki lingkungan $(65,27 \%)$ perawatan berpusat keluarga $(63,32 \%)$, dan manajemen nyeri dan stres bayi $(66,53 \%)$. Data ini menunjukkan bahwa asuhan perkembangan sudah dilakukan cukup baik walaupun belum semua standar diterapkan seperti positioning dan handling, perlindungan kulit dan mengoptimalkan nutrisi (Altimier \& Phillips, 2013).

Asuhan perkembangan yang diteliti oleh Zhang et al. (2014) menemukan faktor besar yang berkontribusi dalam penerapannya yaitu jumlah kasus pasien, jumlah jam kerja per hari, tingkat pendidikan, dan lama bekerja di ruang perawatan neonatus. Penerapan asuhan perkembangan juga dapat ditentukan dari adanya koordinasi staf dan perawat, biaya pengadaan ruangan NICU, fasilitas, dan kepemimpinan perawat 
teregister (Hendricks-Munoz \& Prendergast, 2007). Selain itu, penerapan asuhanperkembangan juga ditentukan oleh pemahaman dan keterampilan dari staf pelayanan kesehatan terutama perawat yang setiap hari melakukan kontak perawatan dengan bayi baru lahir terutama bayi prematur (Van der Pal, 2007). Perawat neonatus hendaknya memiliki keyakinan yang tinggi dalam melakukan tindakan perawatan. Keyakinan ini disebut dengan istilah efikasi diri. Efikasi diri didapat dari pengalaman diri sendiri, pengalaman orang lain, pengaruh orang lain dan didapat dari respon fisik dan emosi (Bandura, 1997 dalam Dennis, 2002).

Berdasarkan hasil studi pendahuluan di ruang perawatan neonatus level II dan III di rumah sakit di Jakarta ditemukan bahwa belum semua aspek standar asuhan perkembangan diterapkan seperti pengelolaan suara di ruang perawatan namun asuhan perkembangan meliputi proteksi tidur dengan menyediakan nesting, minimal handling, mengurangi pencahayaan serta kangaroo mother care sudah di terapkan. Tujuan dari penelitian ini adalah untuk mengidentifikasi faktor efikasi diriperawat yang berhubungan dengan penerapan asuhan perkembangan pada neonatus.

\section{METODE PENELITIAN}

\footnotetext{
Desain penelitian ini adalah deskriptif korelasi dengan pendekatan cross sectional study. Penelitian ini dilakukan di ruang perawatan neonatus level I, II, III di RSAB Harapan Kita dan RSPAD
}

Gatot Subroto. Dua rumah sakit tersebut telah menerapkan asuhan perkembangan pada neonatus di ruang NICU. Responden penelitian ini adalah perawat neonatus dengan jumlah sampel 82 orang. Teknik pengambilan sampel pada penelitian ini menggunakan metode consecutive sampling. Instrumen yang digunakan adalah lembar kuesioner yang diisi oleh responden. Kuesioner memuat karakteristik responden, kuesioner efikasi diri, dan kuesioner universe developmental care. (UDC). Hasil uji validitas kuesioner efikasi diri $r$ $=0,452-0,663$ dan kuesioner UDC $\mathrm{r}$ $=0,501-0,959$ sedangkan uji reabilitas kuesioner efikasi diri dengan nilai $\alpha$ cronbach $=0,821$ dan kuesioner UDC dengan nilai $\alpha$ cronbach $=0,981$. Etika penelitian pada penelitian ini menganut prinsip autonomy / respect of human dignity, anonimity, beneficence, nonmaleficence (Polit \& Beck, 2012). Analisis data menggunakan analisis univariat, sedangkan analisis bivariat dengan uji $T$ independen.

\section{HASIL DAN PEMBAHASAN}

Sebagian besar perawat yang bekerja di ruang perawatan neonatus berusia 37 tahun (Tabel 1), sebagian besar perawat neonatus berpendidikan D3 (74,4\%), dan pada tabel 2 menunjukkan sebagian besar perawat memiliki efikasi diri baik terhadap penerapan asuhan perkembangan (54,9\%) dengan mayoritas dipengaruhi dari pengalaman orang lain $(89,63)$. Penerapan asuhan perkembangan (developmental care) sebagian besar 
telah diterapkan $(153,32)$ dengan penerapan yang sebagaian besar diterapkan adalah domain manajemen nyeri stres bayi $($ mean $=$ 29,34).

Tabel 1. Distribusi Responden Berdasarkan Usiadi Rumah Sakit di Jakarta Juli - Oktober $(n=82)$

\begin{tabular}{lccc}
\hline Variabel & Median & $\begin{array}{c}\text { Min- } \\
\text { Max }\end{array}$ & 95\% CI \\
\hline Usia & 37,00 & $22-58$ & $37,12-41,27$ \\
\hline Tidak terdistribusi & normal &
\end{tabular}

Tabel 2. Distribusi Responden Berdasarkan Tingkat Pendidikan dan Efikasi diri di Rumah Sakit di Jakarta Juli - Oktober $(\mathbf{n}=82)$

\begin{tabular}{lcc}
\hline \multicolumn{1}{c}{ Variabel } & $\begin{array}{c}\text { Frekuens } \\
\text { i (n) }\end{array}$ & $\begin{array}{c}\text { Persenta } \\
\text { se }(\%)\end{array}$ \\
\hline Tingkat & & \\
Pendidikan & & \\
a. SPK & 0 & 0 \\
b. D III & 61 & 74,4 \\
c. S1 \& S2 & 21 & 25,6 \\
\hline Efikasi Diri & & \\
a. Efikasi diri & 37 & 45,1 \\
$\quad$ kurang & & \\
b. Efikasi diri & 45 & 54,9 \\
$\quad$ baik & & \\
\hline
\end{tabular}

Tabel 3. Distribusi Frekuensi Penerapan Asuhan Perkembangan di Rumah Sakit di Jakarta Juli Oktober $(\mathbf{n}=\mathbf{8 2})$

\begin{tabular}{llll}
\hline Variabel & Mean & SD & 95\%CI \\
\hline Penerapan & 153,32 & 21,12 & 148,68 \\
Asuhan & & & - \\
Perkembangan & & & 157,96 \\
1. Domain & 34,84 & 5,12 & $33,72-$ \\
$\quad$ Proteksi & & & 35,97 \\
$\quad$ Tidur & & & $28,50-$ \\
2. Domain & 29,34 & 3,81 & 30,18 \\
$\quad$ Manajemen \\
$\quad$ Nyeri dan \\
$\quad$ & & & \\
$\quad$ Stres & & & $64,39-$ \\
3. Domain & 33,16 & 4,62 & 67,51
\end{tabular}

\begin{tabular}{llll}
\hline Dukungan & & & \\
ADL & & & $20,66-$ \\
4. Domain FCC & 21,77 & 5,05 & 22,88 \\
5. Domain & & & $32,69-$ \\
$\quad$ Lingkungan & 34,21 & 6,91 & 35,73 \\
$\quad \begin{array}{l}\text { Development } \\
\text { al Care }\end{array}$ & & & \\
Terdistribusi normal & &
\end{tabular}

Pada tabel 3 menunjukkan bahwa perawat sebagian besar telah menerapkan asuhan perkembangan. Domain asuhan perkembangan yang paling banyak diterapkan oleh perawat adalah manajemen nyeri dan stres bayi, sedangkan nilai mean asuhan perkembangan paling rendah yang diterapkan oleh perawat adalah asuhan berpusat pada keluarga. Hasil ini menunjukkan hasil serupa yang ditemukan pada studi pendahuluan bahwa beberapa komponen asuhan perkembangan sudah sebagian besar diterapkan. Hasil penelitian ini juga serupa dengan penelitian Permanasari (2016) dengan metode kuesioner menurut persepsi perawat juga menemukan bahwa empat komponen standar asuhan perkembangan sudah sebagian besar diterapkan perawat dengan masing-masing nilai mean $>4$ (rentang 1-5) meliputi standar perawatan individual, asuhan berpusat pada keluarga, praktik kolaborasi, dan perawatan lingkungan yang mendukung perkembangan bayi.

$$
\text { Penerapan asuhan }
$$

perkembangan yang dilakukan perawat berdasarkan hasil penelitian ini meliputi empat domain yaitu domain proteksi tidur, domain pengkajian dan manajemen nyeristres bayi, domain dukungan aktivitas perkembangan harian bayi, domain perawatan berpusat pada keluarga, dan domain lingkungan yang menyembuhkan. Domain yang dilakukan oleh perawat berdasarkan hasil penelitian ini memang lebih 
dominan pada domain dukungan aktivitas perkembangan harian bayi seperti pengaturan posisi bayi, menilai kesiapan makan oral bayi, dan memandikan bayi sekali dalam tiga hari dikarenakan kegiatan tersebut dilakukan bersamaan dengan kegiatan rutin neonatus yang secara tidak langsung berperan dalam meminimalkan pengeluaran energi secara berlebihan oleh neonatus (Alligood, 2014).

Empat domain asuhan perkembangan yang diterapkan sebagian kecil perawat berdasarkan hasil penelitian ini memberikan gambaran bahwa perawat telah menerapkan asuhan perkembangan sesuai prinsip konservasi energi walaupun tidak diterapkan secara optimal. Domain proteksi tidur yang dilakukan perawat seperti menyediakan sesuatu untuk meningkatkan tidur neonatus seperti penggunaan nesting dan mengurangi pencahayaan di tempat tidur dapat menjaga pengeluaran energi minimal neonatus, begitu juga dengan penerapan asuhan perkembangan perawat pada domain manajemen nyeri-stres neonatus yang menerapkan teknik farmakologis dan nonfarmakologis untuk meminimalkan stres atau nyeri neonatus, domain perawatan berpusat pada keluarga dengan melibatkan terutama orang tua neonatus untuk ikut dalam aktivitas perawatan seperti perawatan skin to skin contact dengan neonatus, serta domain lingkungan yang menyembuhkan neonatus baik dengan meminimalkan level suara dari peralatan maupun suara dari staf perawatan dan meminimalkan level pencahayaan. Semua domain penerapan asuhan perkembangan tersebut dilakukan dalam rangka menjaga keutuhan neonatus beradaptasi optimal dengan lingkungan (Alligood, 2014).

Tabel 4. Hubungan antara usia, Tingkat Pendidikan, dan Efikasi Diri dengan Penerapan Asuhan Perkembangan di Rumah Sakit di Jakarta Juli - Oktober (n=82)

\begin{tabular}{|c|c|c|}
\hline \multirow[t]{2}{*}{ Variabel } & \multicolumn{2}{|c|}{$\begin{array}{ll}\text { Penerapan Asuhan } \\
\text { perkembangan }\end{array}$} \\
\hline & $\mathbf{r}$ & Nilai p \\
\hline Usia & 0,266 & 0,016 \\
\hline Tingkat & & 0,770 \\
\hline Pendidikan & & \\
\hline Efikasi diri & & 0,017 \\
\hline
\end{tabular}

Hasil penelitian ini memperlihatkan adanya hubungan yang signifikan antara usia dengan penerapan asuhan perkembangan (developmental care) oleh perawat. Robbins dan Judge (2008) menyatakan bahwa semakin bertambah usia seseorang maka akan membawa sifat-sifat positif dalam pekerjaannya. Papalia, Old, dan Feldman (2011) menyatakan bahwa semakin meningkat usia maka akan semakin meningkatkan kematangan seseorang secara psikologis.

Nilai korelasi Pearson sebesar 0,266 menunjukkan arah korelasi positif namun memiliki hubungan sedang yaitu nilai $\mathrm{r}=0,26-0,50$ (Colton, dalam Sabri \& Hastono, 2014) yang berarti semakin meningkat usia perawat dalam merawat neonatus maka semakin meningkat penerapan asuhan perkembangan pada neonatus sebesar 0,266 kali. Kekuatan yang sedang pada nilai korelasi ini menurut asumsi peneliti adalah bahwa banyak perawat dari berbagai jenis usia belum terbiasa terhadap penerapan asuhan perkembangan 
(developmental care) sebagai metode baru dalam peningkatan kualitas perkembangan neonatus baru lahir. Hal ini menurut peneliti dapat disebabkan karena kurangnya pengetahuan yang memadai mengenai asuhan perkembangan terutama di ruang perawatan neonatus level I yang lebih dominan merawat neonatus yang lahir sehat dan tanpa perlu banyak bantuan peralatan sehingga kurang difokuskan untuk menerapkan asuhan perkembangan.

Hasil penelitian ini menunjukkan tidak ada hubungan antara tingkat pendidikan dengan penerapan asuhan perkembangan. Hal ini dikarenakan perawat dengan tingkat pendidikan rendah dengan tingkat pendidikan tinggi hampir sama dalam menerapkan asuhan perkembangan. Menurut Notoatmodjo (2003), pengetahuan diperlukan sebagai dorongan psikis atau stimulasi dalam menumbuhkan sikap dan perilaku seseorang sehingga dalam penelitian ini perawat yang berpendidikan tinggi dan rendah dapat menerapkan asuhan perkembangan karena memiliki pengetahuan yang didapat dari orang lain.

Efikasi diri merupakan penilaian kemampuan individu sejauhmana untuk melakukan sesuatu (Bandura dalam Dennis, 2002). Hasil penelitian ini menunjukkan bahwa sebagian besar perawat meyakini secara baik mengenai asuhan perkembangan. Hal ini juga menunjukkan bahwa persepsi yang positif dapat mengubah pola pikir dan sikap seseorang untuk membentuk suatu harapan dalam bertindak mencapai sesuatu.

Hasil analisis bivariat ini yang menunjukkan ada hubungan antara efikasi diri dengan penerapan asuhan perkembangan. Perawat yang memiliki efikasi diri baik atau kurang sebagian besar didapat dari pengalaman orang lain dan pengaruh orang lain. Penelitian ini sesuai dengan teori efikasi diri Bandura bahwa seseorang akan memiliki efikasi diri atau memiliki efikasi diri yang tinggi jika telah mendengar atau melihat keberhasilan yang dialami orang lain sehingga lebih mudah untuk mencapai tujuan (Dennis, 2002). Hal ini menunjukkan bahwa pengalaman orang lain juga berkaitan dengan pengalaman kerja yang dimiliki perawat sebagai tolak ukur menerapkan asuhan perkembangan. Dengan demikian, perawat diharapkan meningkatkan efikasi diri melalui keberhasilan orang lain menerapkan asuhan perkembangan yang dapat diperoleh melalui orang yang lebih ahli di tempat pelatihan.

\section{SIMPULAN}

Karakteristik rumah sakit tempat penelitian yang berbeda walaupun sudah sama-sama menerapkan asuhan perkembangan. RSAB Harapan Kita memiliki dua unit ruang perawatan neonatus yaitu unit ruang khusus level III dan unit gabungan ruang level I - II sedangkan ruang perawatan neonatus level I, II, dan III di RSPAD Gatot Subroto di gabung dalam satu unit. Perawat yang 
bekerja di ruang neonatus RSPAD kemungkinan akan lebih sering merawat neonatus di level yang berbeda terutama saat perawat shift dinas berjumlah sedikit dan tidak sesuai dengan jumlah pasien, sehingga kemungkinan perawat dengan tingkat pengetahuan seharusnya di ruang neonatus level I menjadi merawat neonatus di level III.

\section{SARAN}

Pelayanan kesehatan (rumah sakit) yang telah memiliki ruang perawatan neonatus hendaknya memfasilitasi perawat dalam mengikuti pelatihan atau mengadakan pelatihan dan menyediakan dana agar perawat neonatus dapat mengikuti pelatihan terkait developmental care di ruang neonatus.

\section{DAFTAR PUSTAKA}

Alligood, M.R. 2014,"Nursing theorists and their work (8th ed)". USA: Elsevier

Altimier, L.\& Phillips, R.M. 2013, "The neonatal integrative developmental care model: Seven neuroprotective core measures for family-centered developmental care". Newborn \& Infant Nursing Reviews, vol. 13, pp. 9-22.

Dennis, C. 2002,"The brestfeeding sefl efficacy scale: Psychometric assessment of the short form",Journal of Obstetric Gynecologic \&
Neonatal Nursing, vol. 32(6), pp. 734-744.

Godarzi, Z., Rahimi, O., Khalessi, N., Soleimani, F., Mohammadi, N. \& Shamshiri, A. 2015,"The rate of developmental care delivery in neonatal intensive care unit", Iran Journal Critical Care Nursing, vol. 8(2), pp. 117-124.

Herliana, L. 2012,"Pengaruh developmental care terhadap respon nyeri akut pada bayi prematur yang dilakukan prosedur invasif di $R S U$ Tasikmalaya dan RSU Ciamis", (Tesis tidak dipublikasi, Universitas Indonesia). Diakses dari http://www.lib.ui.ac.id

$\begin{array}{rr}\text { Hendricks-Munoz, } & \text { K.D.\& } \\ \text { Prendergast, } & \text { C.C. }\end{array}$ 2007,"Barriers to provision of developmental care in the neonatal intensive care unit: Neonatal nursing perceptions",American Journal of Perinatology, vol. 24, pp. 71-78.

Kenner, C. \& McGrath, J.M. 2004,"Developmental care of newborns \& infants: A guide for healthprofessionals", St. Louis: Mosby

Kiechl-Kohlendorfer, U., Merkle, U., Deufert, D., Neubauer, V., Peglow, U.P. \& Griesmaier, E. 2015,"Effect of developmental care for very premature infants on neurodevelopmental outcome at 2 years of 
age",Infant Behaviour \& Development, vol. 39,pp. 166172.

Mosqueda, R., Castilla, Y., Perapoch, J., de la Cruz, J., LopezMaestro, M. \& Pallas, C. 2013,"Staff perceptions on newborn individualized developmental care and assessment program (NIDCAP) during its implementation in two Spanish neonatal units",Early Human Development, vol. 89, pp. 2733.

Notoatmodjo, S. 2003. "Ilmu kesehatan masyarakat,,Jakarta: Rineka Cipta.

Papalia, D.E., Old, S.W. \& Feldman, R.D. 2011,"Human development (Psikologi perkembangan), Edisi 9". (Alih bahasa: Anwar, A.K). Jakarta: Kencana Perdana Group. (Asli dipublikasi 2008).

Permanasari, I. 2016,"Hubungan penerapan asuhan perkembangan oleh perawat dengan kepuasan orang tua bayi prematur di ruang neonatus", (Tesis tidak dipublikasi, Universitas Indonesia).

Polit, D.F.\& Beck, C.T. 2012,"Nursing research generating and asseing evidence for nursing practice", China: Lippincott Williams \& Wilkins.
Robbins, S.P.\& Judge, T.A. 2008. "Perilaku organisasi", Jakarta: Salemba.

Sabri, L.\& Hastono, S.P. 2014,"Statistik kesehatan, Edisi 1”. Jakarta: Rajawali Pers.

Van der Pal, S.M., Maguire, C.M., Cessie, S.L., Veen, S., Wit, J.M., Walther, F.J. \& Bruil, J. 2007,"Staff opinion regarding the Newborn Individualized Developmental Care and Assessment Program (NIDCAP)",Early Human Development, vol. 83(7), pp. 433-442.

World Health Organization. 2012, "Born too soon: The global action report on preterm birth", Retrieved from www.who .int/pmnch/media/news/2012/ preterm_birth_report/en/index/h tml.

Zhang, X., Lee, S.Y., Chen, J. \& Liu, H. 2014,"Factors influencing implementation of developmental care among NICU nurses in China", Clinical Nursing Research,pp. 1-16. 